\title{
Educational Complexity and Professional Development: Teachers' Need for Metacognitive Awareness
}

\author{
Andrew J. Hughes
}

\begin{abstract}
The study was designed to investigate technology and engineering teachers' metacognitive awareness during specific established teacher practices. The study had a sample size of 18. There were six participants in three groups. Group 1 consisted of teachers that actively participated in Transforming Teaching through Implementing Inquiry (T2I2) professional development program. Group 2 consisted of teachers that were selected for but did not actively participate in T2I2 professional development system. Group 3 consisted of teachers that completed the National Board for Professional Teaching Standards professional development program. To measure the metacognitive awareness of each group, a semi-structured open-ended interview was used. The interviews were analyzed by two independent coders using a coding rubric. The coded interviews established the phenomenological metacognitive awareness of each group.
\end{abstract}

Keywords: Professional development, metacognitive awareness, technology and engineering education

Metacognitive awareness is the ability to recognize and regulate one's own thinking in real time. Metacognitive awareness is the term used to describe an individual's ability to detail their knowledge and regulation of cognition (Schraw \& Dennison, 1994). Knowledge of cognition and regulation of cognition are two predominant components of metacognition. Examples of metacognitive subcomponents under knowledge of cognition include declarative, procedural, and conditional knowledge, and examples of metacognitive subcomponents under regulation of cognition include planning, monitoring, organizing (information management), debugging, and evaluating (Schraw, 2001; Schraw \& Dennison, 1994).

The term declarative knowledge refers to the knowledge that a person has about their cognitive strategies, skills, and abilities (Schraw, 2001). A person with declarative knowledge knows what impacts their learning and the learning of others and what they do and do not know. A person with declarative knowledge knows strategies that can be used to increase performance for completing tasks. The term procedural knowledge refers to a person's knowledge about how to use strategies and techniques to increase performance and accomplish cognitive tasks (Schraw, 2001). A person with procedural knowledge will complete tasks by sequencing known strategies. The term conditional knowledge refers to the knowledge that a person has regarding when and why to use strategies for accomplishing tasks (Schraw, 2001). A person with conditional knowledge knows when and why to 
present an idea and to use strategies for completing tasks. A person with conditional knowledge can rationalize the use of specific strategies and appropriately use strategies based on the scenario.

The term planning is used to describe a person's ability to select appropriate strategies, set goals, and allocate resources (Schraw, 2001). Planning relates to a person's utilization of planning strategies, goal setting, and resources related to accomplishing tasks. The organizing subcomponent relates to the information management sub-process (Pucheu, 2008). Organizing is the use of cognitive strategies and techniques to manage information (Pucheu, 2008). Information management is the active process of organizing, elaborating, summarizing, and selectively focusing on important information for mental restructuring due to cognitive dissonance (Pucheu, 2008). During monitoring, a person assesses their cognition and strategy effectiveness (Schraw, 2001). When teachers are monitoring, they add the assessment of students' thinking through verbal and nonverbal feedback to determine their own effectiveness. During the process of debugging a person uses strategies to identify and correct errors and assumptions about tasks and implemented strategies (Pucheu, 2008). The subcomponent of evaluating is the post hoc analysis of performance and strategy effectiveness (Pucheu, 2008).

The varying complexity and duration of problems that teachers experience indicates their need for metacognition in terms of improved regulation of cognition (Hartman, 2001; Kramarski \& Michalsky, 2009) and knowledge of cognition (Schraw, 2001; Wilson \& Bai, 2010). Teachers that lack an awareness of their own cognitive abilities will have difficulty adapting in the constantly evolving educational environment (Kramarski \& Michalsky, 2009; Lin, Schwartz, \& Hatano, 2005). Prior research has established a link between teacher's metacognitive skills and the effectiveness of their teacher practices (Georghiades, 2004; Gourgey, 1998; Hartman, 2001). Metacognitive awareness is also foundational in a person's ability to learn (Ertmer \& Newby, 1996). Teachers with higher levels of metacognitive awareness have improved learning capability and the ability to translate learning from professional development into classroom practices (Bransford, Brown, \& Cocking, 2000; Ertmer \& Newby, 1996; Pucheu, 2008).

According to Bybee and Loucks-Horsley (2000), "professional development will provide the opportunities for technology teachers and other educators to learn what they need to know and be able to do as they assist students" (p. 32) with learning, but only if teachers have the "cognitive selfawareness necessary for the kinds of metacognitive capabilities required to transfer professional development training into effective classroom practices (Bransford, Brown \& Cocking, 1999; Graber, 1998; Palincsar \& Brown, 1984)" (Pucheu, 2008, p. 7). The term professional development (PD) refers to teachers' improvement or growth of skills and knowledge, primarily with the aim of improving student achievement (Guskey, 2003; Loucks-Horsley, Hewson, Love, \& Stiles, 1998). The literature presents numerous characteristics deemed 
essential for increasing the effectiveness of PD (Guskey, 2003; Mundry, 2007; Smylie, Allensworth, Greenberg, Harris, \& Luppescu, 2001; WestEd, 2000). Gusky (2003) pointed out that not all the literature agrees on specific characteristics of effective professional development. Mundry (2007) indicated that even without "an empirically-based consensus of what constitutes effective professional development (Guskey, 2003; Whitehurst, 2002) there is a knowledge base about learning to guide the design and implementation of teacher learning programs (Elmore, 2002; Loucks-Horsley, Love, Stiles, Mundry \& Hewson, 2003)" (p. 1). The ability of professional development designers to determine teachers' current level of metacognitive awareness and incorporate the further development of metacognitive awareness early on and throughout PD may impact teachers' learning ability (Ertmer \& Newby, 1996; Prytula, 2012), development of pedagogical knowledge (Kramarski \& Michalsky, 2009), and ability to transfer learned content back into their classrooms (Pucheu, 2008).

The research presented in this article aims to describe three different groups of teachers' metacognitive awareness while performing established teacher practices. To describe each group's metacognitive awareness, a semi-structured open-ended interview was used. The interview was designed to gather a perspective of participant's metacognitive awareness during specific teacher practices. Participants were divide into groups based on their participation in one of two different PD programs. Even though the two PD programs offered metacognitive experiences, the development of metacognitive awareness was not a focal point of either program. The findings presented in this article suggest that each group's prior level of metacognitive awareness was a factor in their successful completion of the PD program. Additionally, the findings suggest that each group's metacognitive awareness related to established teacher practices was a factor in their ability to manage educational complexity by adapting these practices.

\section{Background}

This study was conducted in the context of a PD system called Transforming Teaching through Implementing Inquiry (T2I2), a project funded for 4 years by the National Science Foundation. ${ }^{1}$ The project started in fall 2011 with the development of a highly interactive cyberinfrastructure system for delivering research-based PD. The PD was designed for secondary technology and engineering teachers in Grades 6-12. There were five primary goals that the designers of T2I2 attempted to accomplish. The first goal for the T2I2 program was increasing the participating teachers' ability to manage, monitor, adjust, and contribute in the learning environment. The second goal was to increase

\footnotetext{
${ }^{1}$ For more information about the creation of the T2I2 program, see Ernst, Clark, DeLuca, and Bottomley (2013).
} 
teachers' understanding of engineering design concepts and the ability to effectively teach these concepts. The third goal was to increase the teachers understanding of and ability to address student learning needs. The fourth goal was increasing teachers' instructional abilities with the use of self-assessment. The final goal was to promote technology and engineering teachers' attainment of National Board Certification by aligning T2I2 with National Boards for Professional Teaching Standards (NBPTS) in three key ways: (a) the primary goals of T2I2 align with the overall goals of NBPTS, (b) the 17 learning objects of T2I2 were aligned with the 13 Career and Technical Education standards within NBPTS, and (c) T2I2 aligns with NBPTS by using shorter versions of the same teacher artifacts used by NBPTS.

Although the process of completing both the T2I2 and the NBPTS PD programs involves numerous metacognitive experiences, the importance of these experiences in developing metacognitive awareness is not communicated to participants or identified as the primary focus of either program. Because metacognitive awareness is involved throughout these experiences, it stands to reason that a teacher with already high levels of metacognitive awareness would have an easier time completing either PD program.

\section{Rationale}

The purpose of this research was to understand technology and engineering teachers' level of metacognitive awareness in comparison to their participation and completion of either the T2I2 or the NBPTS PD program. This study was informed by research design, metacognitive, and PD literature. The literature indicated that metacognitive research often focuses on students' thinking and regulation because of the belief that metacognitive awareness helps students become better, more self-regulated learners (Schraw, 2001). However, the focus of metacognitive research has been shifting from the students to teachers due to the belief that teachers who lack metacognitive awareness are unable to help students develop their metacognitive awareness (Kramarski \& Michalsky, 2009; Prytula, 2012; Pucheu, 2008). The belief that metacognitively aware teachers can help students develop their metacognitive awareness has prompted interest in PD with varying levels of focus on metacognitive awareness (Prytula, 2012; Pucheu, 2008).

A phenomenological approach was selected for this study to describe participant's metacognitive awareness related to their teacher practices (Creswell, 2007). As a phenomenological study, the research design used qualitative, semi-structured, open-ended interviews to help understand each group's metacognitive awareness during established teacher practices (Creswell, 2007; Denzin \& Lincoln, 1994). The metacognitive awareness interview was designed to gather a more complete perspective of the participant's metacognitive awareness (Bryman, 2006; Creswell, 2007; Denzin \& Lincoln, 1994). The semi-structured and open-ended characteristics of the interview 
enabled participants to provide an uninfluenced depth to their responses and promoted emergence of themes and patterns stated by each group (Akturk \& Sahin, 2011; Creswell, 2007; Denzin \& Lincoln, 1994). Interviewing with broad open-ended questions to investigate metacognition was supported by the literature (Akturk \& Sahin, 2011; Prytula, 2012).

Questions from the metacognitive awareness interview asked the participants to detail their thinking during cognitive tasks including planning, monitoring, organizing, information management, debugging, and evaluating. Participants' ability to describe their mental phenomenon was used to indicate a level of metacognitive awareness (Georghiades, 2004, p. 374). Literature supported listening to the interviewees with as few interruptions to their responses as possible (Creswell, 2007; Denzin \& Lincoln, 1994). The findings were used to provide a detailed description of the three groups' metacognition during common teacher practices.

\section{Instrumentation}

\section{Method}

The metacognitive awareness interview (see Table 1) was modeled based on the components and subcomponents of the Metacognitive Awareness Inventory (MAI; Schraw \& Dennison, 1994). The metacognitive awareness interview consisted of 11 questions, including three parts to Question 4 and two parts to Question 8. The metacognitive awareness interview questions were based on the regulation of cognition subcomponents from the MAI. Additional questions were infrequently used to guide the interviewee if the interviewer felt that they were straying from the focus of the question. The interviews were audio recorded and then transcribed for analysis.

The transcribed interviews were analyzed by two trained coders using a coding rubric. The coding rubric was generated based on the metacognitive awareness subcomponent definitions from the MAI literature. The metacognitive awareness subcomponent definitions are the descriptions of evaluated items listed in the rubric. The coding rubric was organized according to the questions in the metacognitive awareness interview, the components of metacognitive awareness, and the levels of awareness. 
Table 1

Metacognitive Awareness Interview

\begin{tabular}{|c|c|}
\hline $\begin{array}{l}\text { Question } \\
\text { number }\end{array}$ & Interview question \\
\hline 1 & Describe a method you use for planning instruction. \\
\hline 2 & Describe a method you use for planning assessment. \\
\hline 3 & Describe how you organize your instruction. \\
\hline 4.1 & $\begin{array}{l}\text { Remembering that there are multiple types of information; } \\
\text { describe how you inwardly interpret information? }\end{array}$ \\
\hline 4.2 & $\begin{array}{l}\text { How do you inwardly interpret unspoken information from } \\
\text { your students? }\end{array}$ \\
\hline 4.3 & $\begin{array}{l}\text { How do you inwardly interpret a new technique learned from } \\
\text { another teacher or a professional development? }\end{array}$ \\
\hline 5 & Describe how you monitor during instruction. \\
\hline 6 & Describe how you monitor during assessment. \\
\hline 7 & Describe how you adjust your teaching during a lesson. \\
\hline 8.1 & Do you self-evaluate after the instructional process? \\
\hline 8.2 & Describe how you self-evaluate after the instructional process \\
\hline
\end{tabular}

\section{Participants}

The participants in this study were divided into three groups: (Group 1) teachers who actively participated and completed the T2I2 system, (Group 2) teachers who had been selected for but did not participate, completing less than $11 \%$ of the T2I2 system, and (Group 3) teachers who had received National Board Certification in Career and Technical Education (CTE) from the NBPTS program. This study included technology and engineering teachers from three states: Illinois, North Carolina, and Virginia. Participants from these three states applied and were randomly selected for participation in the T2I2 pilot Years 1 (2012-2013) or 2 (2013-2014). Teachers for Group 3 were also identified from these three states. The participants in Group 3 were identified through the NBPTS's website. All National Board Certified Teachers, their states, counties, certification areas, and certification expiration dates were listed. Teachers on the list were filtered by state and by CTE certification. Participants in Group 3 were identified as possible participants only if they had a currently valid NBPTS certification in CTE and were currently teaching technology and engineering education in one of the three states. A total of 73 state-certified technology and engineering teachers were initially identified for possible participation in this study; each teacher was connected to either the T2I2 or the NBPTS PD program. In order to have equal group sizes, 10 teachers from each group where randomly selected to participate. 
The 30 teachers received an email explaining the study and requesting their participation. A total of 18 teachers, six from each group, responded with interest in participating with the study (Table 2). After participants made an informed decision to participate, each was assigned a unique identifying number. The participant's interview recording and interview transcript were encrypted with the unique number. The participants were sent an email in which they were asked to specify a phone number, date, and, time for the interview. Interviews were conducted by phone at the specified date and time.

Table 2

Participant Group Demographics

\begin{tabular}{|c|c|c|c|c|c|c|c|}
\hline \multirow[b]{3}{*}{ Group } & \multicolumn{7}{|c|}{ Variables } \\
\hline & \multicolumn{2}{|c|}{$\begin{array}{c}\text { Gender } \\
n(\%)\end{array}$} & \multicolumn{3}{|c|}{ Experience } & \multicolumn{2}{|c|}{$\begin{array}{c}\text { Grade level taught } \\
n(\%)\end{array}$} \\
\hline & Male & Female & $n$ & $\begin{array}{c}\text { Mean } \\
\text { (years) }\end{array}$ & $S D$ & $\begin{array}{l}\text { Middle } \\
\text { school }\end{array}$ & $\begin{array}{l}\text { High } \\
\text { school }\end{array}$ \\
\hline 1 & $5(83.3 \%)$ & $1(16.6 \%)$ & 6 & 20 & 11 & $3(50 \%)$ & $3(50 \%)$ \\
\hline 2 & $4(66.7 \%)$ & $2(33.3 \%)$ & 6 & 17.3 & 8.5 & $1(16.7 \%)$ & $5(83.3 \%)$ \\
\hline 3 & $3(50 \%)$ & $3(50 \%)$ & 6 & 21.5 & 8.2 & $3(50 \%)$ & $3(50 \%)$ \\
\hline Combined & $12(66.6 \%)$ & $6(33.3 \%)$ & 18 & 19.6 & 8.9 & $7(38.9 \%)$ & $11(61.1 \%)$ \\
\hline
\end{tabular}

\section{Procedure}

The study was conducted over a 16-week period during fall 2014. The metacognitive awareness interview was used to gather a thorough perspective of each participant's metacognitive awareness during common teaching practices. In an attempt to build rapport with the participant, the interviewer began the interview by asking questions about the participant's background and experience related to teaching. Additional guiding questions were used at times to help the participant provide sufficient detail regarding aspects of their metacognitive awareness. The recorded interviews were transcribed and later coded by two independent and trained coders using a coding rubric (Table 3 ).

The two coders were selected based on their experience in teaching and qualitative research. Coder 1 had taught for six years at nearly all levels $\mathrm{K}-16$. Coder 1 had also been involved numerous times in the collection and analysis of qualitative research data. Coder 2 had spent 33 years teaching at the elementary and middle school level. Coder 2 had frequently performed qualitative data collection and analysis during their career. Prior to coding, personal and identifying information were removed from the transcripts. To aid the coding process, each transcript was bracketed into sections based on the interview 
questions. The coders were not informed about any characteristics of the participant, including their assigned group. Each transcript was then axial coded using the coding rubric (Creswell, 2007).

The coders had to be trained regarding axial coding. Axial coding is the process of coding using contextual themes to encompass a phenomenon like metacognitive awareness. The training consisted of the coders reading, discussing, and rationalizing their codes based on the rubric for two transcripts. The coders completed all coding with the trainer present. During the training, the coders would frequently ask the trainer about the appropriate code to assign for a transcript section. The trainer would encourage the use of the coding rubric. The trainer would ask the coders to compare the transcript section to the corresponding descriptors in the coding rubric and to indicate the appropriate code from the rubric based on the content of that section. The coders independently used the rubric to identify each participant's level of knowledge and regulation of cognition based on their answers to the interview questions.

Table 3

Metacognitive Awareness Interview Coding Rubric

\begin{tabular}{|c|c|c|c|c|c|c|}
\hline $\begin{array}{l}\text { Question } \\
\text { focus: Sub- } \\
\text { component }\end{array}$ & $\begin{array}{c}\text { Component } \\
\text { of meta- } \\
\text { cognitive } \\
\text { awareness }\end{array}$ & $\begin{array}{l}\text { High level } \\
\text { of meta- } \\
\text { cognitive } \\
\text { awareness } \\
(5)\end{array}$ & $\begin{array}{l}\text { High to } \\
\text { medium } \\
\text { level of } \\
\text { meta- } \\
\text { cognitive } \\
\text { awareness } \\
\text { (4) }\end{array}$ & $\begin{array}{l}\text { Medium } \\
\text { level of } \\
\text { meta- } \\
\text { cognitive } \\
\text { awareness } \\
\text { (3) }\end{array}$ & $\begin{array}{l}\text { Medium to } \\
\text { low level of } \\
\text { meta- } \\
\text { cognitive } \\
\text { awareness } \\
\text { (2) }\end{array}$ & $\begin{array}{l}\text { Low level } \\
\text { of } \\
\text { metacogniti } \\
\text { ve } \\
\text { Awareness } \\
\text { (1) }\end{array}$ \\
\hline $\begin{array}{l}\text { Declarative, } \\
\text { procedural } \\
\text { and } \\
\text { conditional } \\
\text { knowledge: } \\
\text { Questions } 1 \text {, } \\
2,3,4,5,6 \text {, } \\
7 \text {, and } 8\end{array}$ & Knowledge & $\begin{array}{l}\text { The } \\
\text { participant } \\
\text { describes a } \\
\text { strategy; } \\
\text { how to use } \\
\text { the } \\
\text { strategy, } \\
\text { why the } \\
\text { strategy } \\
\text { was used in } \\
\text { cognitive } \\
\text { terms, and } \\
\text { how they } \\
\text { knew that } \\
\text { was the } \\
\text { strategy to } \\
\text { use in } \\
\text { cognitive } \\
\text { terms. }\end{array}$ & $\begin{array}{l}\text { The } \\
\text { participant } \\
\text { describes } 3 \\
\text { of the } 4 \\
\text { listed in the } \\
\text { column } \\
\text { High Level } \\
\text { of Meta- } \\
\text { cognitive } \\
\text { Awareness. }\end{array}$ & $\begin{array}{l}\text { The } \\
\text { participant } \\
\text { describes } 2 \\
\text { of the } 4 \\
\text { listed in the } \\
\text { column } \\
\text { High Level } \\
\text { of Meta- } \\
\text { cognitive } \\
\text { Awareness. }\end{array}$ & $\begin{array}{l}\text { The } \\
\text { participant } \\
\text { describes } 1 \\
\text { of the } 4 \\
\text { listed in the } \\
\text { column } \\
\text { High Level } \\
\text { of Meta- } \\
\text { cognitive } \\
\text { Awareness. }\end{array}$ & $\begin{array}{l}\text { The } \\
\text { participant } \\
\text { does not } \\
\text { describe } \\
\text { any of the } 4 \\
\text { listed in the } \\
\text { column } \\
\text { High Level } \\
\text { of Meta- } \\
\text { cognitive } \\
\text { Awareness. }\end{array}$ \\
\hline
\end{tabular}




\begin{tabular}{|c|c|c|c|c|c|c|}
\hline $\begin{array}{l}\text { Planning } \\
\text { Questions } \\
1 \text { and } 2\end{array}$ & Regulation & $\begin{array}{l}\text { The } \\
\text { participant } \\
\text { describes } \\
\text { planning, } \\
\text { goal } \\
\text { setting, and } \\
\text { allocation } \\
\text { of } \\
\text { resources }\end{array}$ & $\begin{array}{l}\text { The } \\
\text { participant } \\
\text { describes } 2 \\
\text { of the items } \\
\text { in detail } \\
\text { and } 1 \text { item } \\
\text { generally in } \\
\text { the column } \\
\text { High Level } \\
\text { of Meta- } \\
\text { cognitive } \\
\text { Awareness. }\end{array}$ & $\begin{array}{l}\text { The } \\
\text { participant } \\
\text { describes } 2 \\
\text { of the } 3 \\
\text { listed in the } \\
\text { column } \\
\text { High Level } \\
\text { of Meta- } \\
\text { cognitive } \\
\text { Awareness. }\end{array}$ & $\begin{array}{l}\text { The } \\
\text { participant } \\
\text { describes } 1 \\
\text { of the items } \\
\text { in detail } \\
\text { and } 2 \text { items } \\
\text { generally in } \\
\text { the column } \\
\text { High Level } \\
\text { of Meta- } \\
\text { cognitive } \\
\text { Awareness. }\end{array}$ & $\begin{array}{l}\text { The } \\
\text { participant } \\
\text { describes } 1 \\
\text { of the } 3 \\
\text { listed in the } \\
\text { column } \\
\text { High Level } \\
\text { of Meta- } \\
\text { cognitive } \\
\text { Awareness. }\end{array}$ \\
\hline $\begin{array}{l}\text { Organization } \\
\text { Question } 3\end{array}$ & Regulation & $\begin{array}{l}\text { The } \\
\text { participant } \\
\text { describes } \\
\text { the } \\
\text { implement- } \\
\text { ation of } \\
\text { techniques } \\
\text { based on an } \\
\text { under- } \\
\text { standing of } \\
\text { cognition } \\
\text { for the } \\
\text { purpose of } \\
\text { organ- } \\
\text { ization. }\end{array}$ & $\begin{array}{l}\text { The } \\
\text { participant } \\
\text { describes } \\
\text { the } \\
\text { implement- } \\
\text { ation of } \\
\text { techniques } \\
\text { based on an } \\
\text { under- } \\
\text { standing of } \\
\text { cognition } \\
\text { for the } \\
\text { purpose of } \\
\text { organ- } \\
\text { ization. }\end{array}$ & $\begin{array}{l}\text { The } \\
\text { participant } \\
\text { describes } \\
\text { the } \\
\text { implement- } \\
\text { ation of } \\
\text { techniques } \\
\text { for the } \\
\text { purpose of } \\
\text { organ- } \\
\text { ization. }\end{array}$ & $\begin{array}{l}\text { The } \\
\text { participant } \\
\text { describes } \\
\text { generally } \\
\text { the } \\
\text { implement- } \\
\text { ation of } \\
\text { techniques } \\
\text { for the } \\
\text { purpose of } \\
\text { organ- } \\
\text { ization }\end{array}$ & $\begin{array}{l}\text { The } \\
\text { participant } \\
\text { does not } \\
\text { describe the } \\
\text { implement- } \\
\text { ation of } \\
\text { techniques } \\
\text { for the } \\
\text { purpose of } \\
\text { organ- } \\
\text { ization. }\end{array}$ \\
\hline $\begin{array}{l}\text { Information } \\
\text { management } \\
\text { Question } 4\end{array}$ & Regulation & $\begin{array}{l}\text { The } \\
\text { participant } \\
\text { describes } \\
\text { their } \\
\text { cognitive } \\
\text { organ- } \\
\text { ization, } \\
\text { elaboration, } \\
\text { summar- } \\
\text { ization, and } \\
\text { selective } \\
\text { focus on } \\
\text { important } \\
\text { information } \\
\text {. }\end{array}$ & $\begin{array}{l}\text { The } \\
\text { participant } \\
\text { describes } 3 \\
\text { of the } 4 \\
\text { items listed } \\
\text { in the } \\
\text { column } \\
\text { High Level } \\
\text { of Meta- } \\
\text { cognitive } \\
\text { Awareness. }\end{array}$ & $\begin{array}{l}\text { The } \\
\text { participant } \\
\text { describes } 2 \\
\text { of the } 4 \\
\text { listed in the } \\
\text { column } \\
\text { High Level } \\
\text { of Meta- } \\
\text { cognitive } \\
\text { Awareness. }\end{array}$ & $\begin{array}{l}\text { The } \\
\text { participant } \\
\text { describes } 1 \\
\text { of the } 4 \\
\text { listed in the } \\
\text { column } \\
\text { High Level } \\
\text { of Meta- } \\
\text { cognitive } \\
\text { Awareness. }\end{array}$ & $\begin{array}{l}\text { The } \\
\text { participant } \\
\text { does not } \\
\text { describe } \\
\text { any of the } 4 \\
\text { listed in the } \\
\text { column } \\
\text { High Level } \\
\text { of Meta- } \\
\text { cognitive } \\
\text { Awareness. }\end{array}$ \\
\hline $\begin{array}{l}\text { Monitoring } \\
\text { Questions 5 } \\
\text { and } 6\end{array}$ & Regulation & $\begin{array}{l}\text { The } \\
\text { participant } \\
\text { describes } \\
\text { cognitive } \\
\text { assessment } \\
\text { of } \\
\text { themselves, } \\
\text { someone } \\
\text { else, and }\end{array}$ & $\begin{array}{l}\text { The } \\
\text { participant } \\
\text { describes } 2 \\
\text { of the items } \\
\text { in detail } \\
\text { and } 1 \text { item } \\
\text { generally in } \\
\text { the column } \\
\text { High Level } \\
\text { of Meta- }\end{array}$ & $\begin{array}{l}\text { The } \\
\text { participant } \\
\text { describes } 2 \\
\text { of the } 3 \\
\text { listed in the } \\
\text { column } \\
\text { High Level } \\
\text { of Meta- } \\
\text { cognitive } \\
\text { Awareness. }\end{array}$ & $\begin{array}{l}\text { The } \\
\text { participant } \\
\text { describes } 1 \\
\text { of the items } \\
\text { in detail } \\
\text { and } 2 \text { items } \\
\text { generally in } \\
\text { the column } \\
\text { High Level } \\
\text { of Meta- }\end{array}$ & $\begin{array}{l}\text { The } \\
\text { participant } \\
\text { describes } 1 \\
\text { of the } 3 \\
\text { listed in the } \\
\text { column } \\
\text { High Level } \\
\text { of Meta- } \\
\text { cognitive } \\
\text { Awareness. }\end{array}$ \\
\hline
\end{tabular}




\begin{tabular}{|c|c|c|c|c|c|c|}
\hline & & $\begin{array}{l}\text { their } \\
\text { strategy }\end{array}$ & $\begin{array}{l}\text { cognitive } \\
\text { Awareness }\end{array}$ & & $\begin{array}{l}\text { cognitive } \\
\text { Awareness. }\end{array}$ & \\
\hline $\begin{array}{l}\text { Debugging } \\
\text { Question } 7\end{array}$ & Regulation & $\begin{array}{l}\text { The } \\
\text { participant } \\
\text { describes a } \\
\text { strategy } \\
\text { used to } \\
\text { correct per- } \\
\text { formance } \\
\text { errors and } \\
\text { assumption } \\
\text { s they made } \\
\text { about a task } \\
\text { or strategy } \\
\text { used. }\end{array}$ & $\begin{array}{l}\text { The } \\
\text { participant } \\
\text { describes } 1 \\
\text { of the items } \\
\text { in detail } \\
\text { and } 1 \text { item } \\
\text { generally in } \\
\text { the column } \\
\text { High Level } \\
\text { of Meta- } \\
\text { cognitive } \\
\text { Awareness. }\end{array}$ & $\begin{array}{l}\text { The } \\
\text { participant } \\
\text { describes a } \\
\text { strategy } \\
\text { used to } \\
\text { correct per- } \\
\text { formance } \\
\text { errors or } \\
\text { assumpt- } \\
\text { ions they } \\
\text { made about } \\
\text { a task or } \\
\text { strategy } \\
\text { used. }\end{array}$ & $\begin{array}{l}\text { The } \\
\text { participant } \\
\text { generally } \\
\text { describes } 1 \\
\text { of the } 2 \\
\text { aspects in } \\
\text { the column } \\
\text { High Level } \\
\text { of Meta- } \\
\text { cognitive } \\
\text { Awareness. }\end{array}$ & $\begin{array}{l}\text { The } \\
\text { participant } \\
\text { does not } \\
\text { describe a } \\
\text { strategy } \\
\text { used to } \\
\text { correct per- } \\
\text { formance } \\
\text { errors or } \\
\text { assumpt- } \\
\text { ions they } \\
\text { made about } \\
\text { a task or } \\
\text { strategy } \\
\text { used. }\end{array}$ \\
\hline $\begin{array}{l}\text { Evaluating } \\
\text { Question } 8.2\end{array}$ & Regulation & $\begin{array}{l}\text { The } \\
\text { participant } \\
\text { describes } \\
\text { their own } \\
\text { post hoc } \\
\text { analysis of } \\
\text { their per- } \\
\text { formance } \\
\text { and } \\
\text { strategy } \\
\text { effective- } \\
\text { ness. }\end{array}$ & $\begin{array}{l}\text { The } \\
\text { participant } \\
\text { describes } 1 \\
\text { of the items } \\
\text { in detail } \\
\text { and } 1 \text { item } \\
\text { generally in } \\
\text { the column } \\
\text { High Level } \\
\text { of Meta- } \\
\text { cognitive } \\
\text { Awareness }\end{array}$ & $\begin{array}{l}\text { The } \\
\text { participant } \\
\text { describes } \\
\text { their own } \\
\text { post hoc } \\
\text { analysis of } \\
\text { either their } \\
\text { per- } \\
\text { formance } \\
\text { or strategy } \\
\text { effect- } \\
\text { iveness. }\end{array}$ & $\begin{array}{l}\text { The } \\
\text { participant } \\
\text { generally } \\
\text { describes } 1 \\
\text { of the } 2 \\
\text { aspects in } \\
\text { the column } \\
\text { High Level } \\
\text { of Meta- } \\
\text { cognitive } \\
\text { Awareness. }\end{array}$ & $\begin{array}{l}\text { The } \\
\text { participant } \\
\text { does not } \\
\text { describe } \\
\text { their own } \\
\text { post hoc } \\
\text { analysis of } \\
\text { either their } \\
\text { per- } \\
\text { formance } \\
\text { or strategy } \\
\text { effective- } \\
\text { ness. }\end{array}$ \\
\hline
\end{tabular}

The coding took at least two hours for each interview. After reading each section of the transcript, the coder assigned a level from zero (0) to five (5), based on the rubric, to the participant's response. To help prevent miscoding a participant's response, the coders wrote a description based on the coding rubric of areas that the participant did and did not address in their response to each question. The description was used to help identify if a participant's response was correctly assigned a level based on the rubric. During coding, blue highlighters were used to code the regulation of cognition components, and yellow highlighters were used to code the knowledge of cognition components in each transcript. The coders also took notes about each participants' metacognitive awareness level. These notes were used to help each coder write a synopsis about the participant's overall level of metacognitive awareness. The synopses helped to form an apparent view of each participant's metacognitive awareness. Coders also noted participant's responses that were assigned higher levels based on the coding rubric or that responded uniquely.

Using the assigned level from each coder on each interview question, interrater reliability was determined using Cohen's kappa. Cohen's kappa 
compares the first and second coders' assigned levels for all 18 participants and 10 scored response sections in each interview. The 10 responses sections included participants' responses to Questions 1-7 and Question 8.2, including the three parts of Question 4. Because Question 8.1 is a polar question requiring a yes or no answer, it was not scored by the coders. The interviewer attempted to keep the interviews to 1 hour each, and some participants were unable to answer all of the questions in the allotted time. Thus, the total number of compared items was 173 not 180 . The interrater reliability analysis started by checking for miscodes on the transcripts. A miscode was when the coder's assigned level and rationale for that level did not match. The miscodes required the coder to verify and correct their assigned level and rationale. After the miscodes were addressed, the data was entered into SPSS. The Cohen's kappa statistic was then used to analyze the data for interrater reliability. Cohen's kappa indicated that coders had a beyond-chance moderate agreement of $73 \%$, a standard error of .03 , and a $p$-value less than .001 in their assigned levels for the participants' responses.

The researcher compiled the coders' codes, notes, and synopses for each participant into their respective group. Each group's synopses consisted of participant's assigned level of awareness on each of the 10 scored response sections from the interview, their responses that characterized the assigned level of awareness, and the coders' notes and synopses. The combination of these items into a group summary helped characterize each group's metacognitive awareness. After each group's summary was complete, their unique metacognitive awareness themes became evident.

\section{Results}

Each of the three groups was found to have its own unique metacognitive awareness phenomenon while performing common teacher practices. The metacognitive phenomena of each group related to the many facets of the group members' respective teacher practices. Regarding the knowledge of cognition component for all questions, only a few participants belonging to Groups 1 and 3 exhibited medium to high levels of metacognitive awareness. Other than these participants, based on the coded transcripts, each group had a slightly different but overall low to medium level of metacognitive awareness in the knowledge of cognition component. The participants in each group frequently discussed their strategies (declarative knowledge) and infrequently discussed how to use the strategies for planning, organizing, monitoring, debugging, and evaluating (procedural knowledge). Occasionally, a participant from Groups 1 and 3 would also discuss why the strategy was used in terms of cognition. Listed below are representative examples of responses to interview Question 3 that were coded for the knowledge of cognition component. 
Right now, the way I do things primarily is I will introduce the topic, and I can either be just showing slides, or a presentation, or I like to if I can show an audio or a video. (Group 3)

Once they know the information then we will kind of go back and revisit all of that, but in the applicable sense where they're actually going to be performing the task or the skill. (Group 3)

I sit down with the standard course of study, create a pacing guide, roughly when I'm going to teach what, how much time it's going to take, and then create lessons for each day. (Group 2)

Typically, what I'll do is I have a PowerPoint slide that I'll throw up. It'll give the day's agenda for the three different sections I've been teaching for that period, and it'll give specific warm ups. (Group 1)

The participants from Groups 1 and 2 focused on a strategy and generally how to use the strategy for planning and organization. The participants' responses from Group 3 included strategies, generally how to use the strategies, and a conditional reason why the strategy was used in terms of cognition. However, when comparing each group's knowledge of cognition, the groups were similar. The groups' transcripts had specific declarative knowledge, usually general procedural knowledge, and often lacked conditional knowledge.

The groups' answers to interview questions based on the regulation of cognition component were more distinguishably different. Group 3 participants were assigned more high and high-to-medium levels, Group 2 participants' levels ranging from medium to low, and Group 1 participants were assigned more high-to-medium and medium levels. In two cases, a participant from Groups 1 and 2 was assigned a level of 0 . The 0 level was not on the coding rubric, but both coders in both cases recorded a 0 for those participants' responses. For Questions 1 and 2, coders were looking for the participant to describe planning, goal setting, and allocation of resources. Listed below are representative examples of the regulation of cognition coded responses from interview Question 1 dealing with the planning of instruction.

With this unit, I used what the state had provided, but I also sought additional resources by using an opportunity to participate in a grant program. This program provided additional resources for the students to use. (Group 3)

One of the methods I use for planning instruction is called the $5 \mathrm{E}$ 's, and its engagement, evaluation, and it's a couple more. (Group 2) 
I draw on my past experience quite a bit. I take a look at what has worked in the past and maybe what hasn't worked so well and then I formulate my lecture, my demonstrations based on that information. (Group 1)

The passage from the Group 3 participant exemplifies how Group 3 members, those who had National Board Certification, often discussed goals or allocation of resources in addition to planning. Group 3 participants would often focus on two items from the rubric and only provide some detail on the third. The Group 1 passage is primarily focused on planning. Group 1 often focused on planning with brief descriptions of either goal setting or allocation of resources. The passage from Group 2 presents a typical answer from participants in Group 2. The combination of incomplete thoughts and little detail on one or two of the rubric items resulted in low assigned levels of metacognitive awareness in the regulation of cognition component for interview Questions 1 and 2.

Questions 3 and 4 were focused on organization. Question 4 was specific to information management, an aspect of organization. In Question 3, coders were looking for the participant to describe implementation of techniques based on an understanding of cognition for organization. Listed below are representative examples of the responses to interview Question 3 that were coded regulation of cognition.

I would begin with some type of bell ringer. Something to get the students interested in what the topic is for that particular day. (Group 3)

The overall objective for the lesson [was] to draw the kids interest, to help them make connections to the real world. (Group 3)

I try to make them aware of where we are today, where we've come from, and hopefully where we're going to go in the future. (Group 2)

I usually start the class out with some sort of bell ringer, to get them thinking about what it is that we're going to do that day. (Group 1)

By taking it further and possibly doing a hand-on or application project with it, they're involved. (Group 1)

Group 3 participants, the National Board Certified Teachers, were focused on organization, attending to the cognitive needs of the students to keep them interested. Group 2 participants responded to Question 3 in general terms. The coders had difficulty highlighting any significant responses from Group 2 participants. Due to Group 2's generalized responses to Question 3, their focus seemed to be at the macro level of organization. Group 1 participants' answers 
to Question 3 were similar to those of Group 3. Occasionally, participants in Group 1 lacked the level of detail shown in Group 3's responses.

Question 4 was split into three scenarios dealing with information management. The first scenario was a general question about interpreting information. The second scenario was specific to information management of nonverbal feedback from students. The third scenario related to information management of new teaching techniques learned from another teacher or from a PD program. In all three scenarios, coders were looking for the participant to describe their cognitive organization, elaboration, summarization, and selective focus on important information. Listed below are representative examples of the responses to interview Question 4 that were coded as regulation of cognition.

When I receive information, I try to make it relevant to what the situation is as far as my perspective, how I'm going to view it. (Group 3)

When I receive information, I try to internalize it and fully understand the whole concept without just judgment about the information. (Group 3)

I try to sometimes put myself in the position of being someone else. (Group 3)

I get information and sometimes I try to apply it to a project, maybe, the kids are working on. (Group 3)

Based on your experience or based on your colleagues that you're working with or talking to about it, you can evaluate some of the things as yeah, this is really important piece of information that they need to know, or maybe this particular piece of information is not as critical. (Group 2)

I try to put it into some type of situation that I'm maybe familiar with. What am I going to do with this information, how am I going to apply it to something I already know or something that I need to know. (Group 1)

Group 3 participants discussed how they organized information, focused on the important information, and either summarized or elaborated on the information that they received. The Group 2 participants mostly talked about one item specifically, and talked about the other aspects of information management more generally or not at all. In the Group 2 passage above, the participant's entire response was specific to focusing on important information, but the participant neglected any real detail about other aspects of information organization. The Group 1 participant's answers were more associated with the elaboration and summarization of information as well as the general management of information. 
In Questions 5 and 6, the coders were looking for the monitoring subcomponent of cognitive regulation. Based on the rubric, for a participant's response to be coded as a high level, they needed to describe cognitive assessment of each item in detail. All the participants at least described the monitoring of their students. However, Group 2 often did not describe the cognitive assessment portion. Group 2 discussed general monitoring of their students. Only a few participants described the cognitive assessment of themselves or their methods. Only three participants, one from Group 1 and two from Group 3, described in detail the cognitive assessment of themselves, someone else, and their strategy. Listed below are representative examples of the responses coded regulation of cognition from interview question five, which dealt with the monitoring of cognition during instruction.

One team was asking the same question and another team was asking the same question, even though they're two different ability levels then that means I missed it somewhere and I need to go back and cover that. (Group 3)

I will need to change my lesson plan just for that one level and I can remediate with them later or right at that moment. (Group 3)

I walk my classroom and make sure that the students are doing individual work, or if they are working in learning teams then I know what they are doing. (Group 2)

I kind of monitor myself because if what I'm saying doesn't make sense to me ... but I've already said something that after I say that, "wait a minute, what did I just say?” (Group 1)

Question 7 focused on the debugging or adjustment of the teacher's strategy during instruction. The coders were looking for the participant to describe a strategy used to correct performance errors and false assumptions that they had made about the task or strategy being used. None of the participants described the correction of both performance errors and false assumptions with enough detail for both coders to assign a high level of cognitive regulation in the debugging subcomponent. Group 1 provided the most detailed descriptions of their adjustments. Group 1 focused on either errors or assumptions with brief reference to the other aspect of the component. Group 2 received the lowest levels on this component. Both coders wrote that the responses of Group 2 participants were general and sometimes did not seem to provide a direct answer to Question 7. Group 3 answered similarly to Group 1 but lacked the same level of detail. The coders considered Group 3 participants to be more at the medium level of metacognitive awareness for the debugging subcomponent based on the 
coding rubric. Listed below are representative examples of the regulation of cognition coded responses from interview Question 7.

I adjust my teaching during the lesson based on how I think the lesson is going ... whether it's contextual feedback or if it's a spoken-type of feedback or body language. I adjust my lesson just based on what I see if it's working or not. (Group 3)

I'm trying to make sure that I'm not losing some of them. If I do I try to back up and show a different way to do a particular thing. (Group 2)

I might backtrack and re-explain something. I might try a different way of explaining something ... switch people to different groups ... I might try to find a totally different way to explain something. Some groups, I might do hands-on activities. Other groups, I might show a video or see a PowerPoint, just depending on the dynamics. (Group 1)

Part two of Question 8 was about the participants' cognitive self-evaluation and reflection. The coders were looking for the participants to describe their own post hoc analyses of their performance and strategy effectiveness. Based on the coding of their responses, the groups all had similar metacognitive awareness on question eight; they were all basically assigned at a medium level of metacognitive awareness. Some of the participants provided somewhat more detail than others, resulting in slightly higher levels of awareness being assigned. All participants focused on reflecting either about their performance or their strategy effectiveness. The participants described how, when, and why they tended to reflect. Some of the participants even described what they did based on decisions made during their self-evaluation. Listed below are representative examples of the regulation of cognition coded responses from interview Question 8.2.

I go back and look at what didn't work, what I need to change. (Group 3)

The next time I teach this lesson, I'm going to do this. I might leave this part off. That's basically how I plan. (Group 3)

You have to look back on it, and say, "well, that really didn't go well that way, next time I can try it this way." (Group 2)

A lot of times driving home I'll think about what I did that day. Did it work? How can I do something a little different? Make it a little better, make it a little more interactive. (Group 2) 
I try to make little notes to myself about what went right, what went wrong, come up with ideas on how I could change things and do thing differently.

(Group 1)

\section{Implications}

The first finding from this study indicated that all three groups had similar levels of metacognitive awareness in the knowledge of cognition component. Coders indicated based on the coding rubric that participants typically ranged from medium to low levels of cognitive knowledge. The literature, especially in technology and engineering related $\mathrm{PD}$, has discussed the importance of content and pedagogical knowledge in PD (Bybee \& Loucks-Horsley, 2000; Daugherty \& Custer, 2012; Mundry, 2007; WestEd, 2000). Content and pedagogical knowledge are often considered foundational characteristics of effective PD (Ball, Thames, \& Phelps, 2008; Bybee \& Loucks-Horsley, 2000; Mundry, 2007). Underlying both content and pedagogical knowledge is knowledge of cognition; the knowledge of strategies, skills, and abilities that impacts a person's learning ability as well as how and why to use strategies and techniques for increasing performance and accomplishing cognitive tasks. Moreover, research indicates that teachers' knowledge of cognition is linked to their learning ability, pedagogical effectiveness, ability to transfer learning from one context to another, and ability to adapt in a complex educational environment (Bransford et al., 2000; Ertmer \& Newby, 1996; Georghiades, 2004; Gourgey, 1998; Hartman, 2001; Kramarski \& Michalsky, 2009; Lin et al., 2005; Pucheu, 2008; Wilson \& Bai, 2010). This would suggest that teacher PD should focus on metacognitive awareness, including knowledge of cognition, because it will impact many common teacher practices.

The second finding from this study indicated that each group had uniquely different metacognitive awareness in the regulation of cognition component. Overall, Groups 1 and 3 had higher levels in regulation of cognition component, and these two groups successfully completed their PD experience. Selfregulation is considered an aspect within the regulation of cognition component of metacognition (Ertmer \& Newby, 1996; Pintrich, Wolters, \& Baxter, 2000). Self-regulation has been identified as a factor in a person actively pursuing the learning process (Ertmer \& Newby, 1996; Pintrich et al., 2000). Regulation of cognition is a decisive factor in teachers' adaptation ability, which helps in solving problems involving information management and reasoning (Hartman, 2001; Kramarski \& Michalsky, 2009; Lin et al., 2005). The complexity that teachers experience each day necessitates their ability to regulate their cognition (Hartman, 2001; Kramarski \& Michalsky, 2009; Lin et al., 2005). Regulation of cognition's role in teachers' learning, ability to adapt, and development throughout their career suggests its importance as a focus in PD programs. 


\section{Conclusions}

The intent of this research was to understand technology and engineering teachers' level of metacognitive awareness in comparison to their participation and completion of either the T2I 2 or the NBPTS program. The findings suggest a connection between teachers' level of metacognitive awareness, successful completion of PD, and ability to manage educational complexity. The results of this study are applicable to future work in improving teacher content and pedagogical knowledge, helping teachers manage educational complexity, helping teachers take an active self-regulated role in PD, and PD effectiveness.

\section{References}

Akturk, A. O., \& Sahin, I. (2011). Literature review on metacognition and its measurement. Procedia Social and Behavioral Sciences, 15, 3731-3736. doi:10.1016/j.sbspro.2011.04.364

Ball, D. L., Thames, M. H., \& Phelps, G. (2008). Content knowledge for teaching: What makes it special? Journal of Teacher Education, 59(5), 389-407. doi:10.1177/0022487108324554

Bransford, J. D., Brown, A. L., \& Cocking, R. R. (Eds.). (2000). How people learn: Brain, mind, experience, and school (Expanded ed.). Washington, DC: National Academy Press. doi:10.17226/9853

Bryman, A. (2006). Integrating quantitative and qualitative research: How is it done? Qualitative Research, 6(1), 97-113. doi:10.1177/1468794106058877

Bybee, R. W., \& Loucks-Horsley, S. (2000). Advancing technology education: The role of professional development. The Technology Teacher, 60(2), 3134.

Creswell, J. W. (2007). Qualitative inquiry \& research design: Choosing among five approaches (2nd ed.). Thousand Oaks, CA: Sage.

Daugherty, J. L., \& Custer, R. L. (2012). Secondary level engineering professional development: content, pedagogy, and challenges. International Journal of Technology and Design Education, 22(1), 51-64. doi:10.1007/s10798-010-9136-2

Denzin, N. L., \& Lincoln, Y. S. (Eds.). (1994). Handbook of qualitative research. Thousand Oaks, CA: Sage.

Ernst, J. V., Clark, A. C., DeLuca, V. W., \& Bottomley, L. (2013, June). Professional development system design for grades 6-12 technology, engineering, and design educators. Paper presented at the 120th ASEE Annual Conference \& Exposition, Atlanta, GA. Retrieved from https://peer.asee.org/22373

Ertmer, P. A., \& Newby, T. J. (1996). The expert learner: Strategic, selfregulated, and reflective. Instructional science, 24(1), 1-24. doi:10.1007/BF00156001 
Georghiades, P. (2004). From the general to the situated: Three decades of metacognition, International Journal of Science Education, 26(3), 365-383. doi:10.1080/0950069032000119401

Gourgey, A. F. (1998). Metacognition in basic skills instruction. Instructional Science, 26(1-2), 81-96. doi:10.1023/A:1003092414893

Guskey, T. R. (2003). What makes professional development effective? Phi Delta Kappan, 84(10), 748-750. doi:10.1177/003172170308401007

Hartman, H. J. (Ed.). (2001). Metacognition in learning and instruction: Theory, research and practice. Dordrecht, the Netherlands: Springer. doi:10.1007/978-94-017-2243-8

Kramarski, B., \& Michalsky, T. (2009). Investigating preservice teachers' professional growth in self-regulated learning environments. Journal of Educational Psychology, 101(1), 161-175. doi:10.1037/a0013101

Lin, X., Schwartz, D. L., \& Hatano, G. (2005). Toward teachers' adaptive metacognition. Educational Psychologist, 40(4), 245-255. doi:10.1207/s15326985ep4004_6

Loucks-Horsley, S., Hewson, P. W., Love, N., \& Stiles, K. E. (1998). Designing professional development for teachers of science and mathematics. Thousand Oaks, CA: Corwin Press.

Mundry, S. (2007, February). Professional development in science education: What works? Paper presented at Professional Development for Engineering and Technology: A National Symposium, Dallas, TX. Retrieved from https://www.researchgate.net/publication/255645159

Pintrich, P. R., Wolters, C. A., \& Baxter, G. P. (2000). Assessing metacognition and self-regulated learning. In G. Schraw \& J. C. Impara (Eds.), Issues in the measurement of metacognition (pp. 43-97). Lincoln, NE: Buros Institute of Mental Measurements.

Prytula, M. P. (2012). Teacher metacognition within the professional learning community. International Education Studies, 5(4), 112-121. doi:10.5539/ies.v5n4p112

Pucheu, P. M. (2008). An investigation of the relationships between the Scoring Rubrics Inventory and the Metacognitive Awareness Inventory as reported by secondary school core-subject teachers (Doctoral dissertation). Available from ProQuest Dissertations and Theses database. (UMI No. 3313868)

Schraw, G. (2001). Promoting general metacognitive awareness. In H. J. Hartman (Ed.), Metacognition in learning and instruction: Theory, research and practice (pp. 3-16). Dordrecht, the Netherlands: Kluwer Academic. doi:10.1007/978-94-017-2243-8_1

Schraw, G., \& Dennison, R. S. (1994). Assessing metacognitive awareness. Contemporary Education Psychology, 19(4), 460-475. doi:10.1006/ceps.1994.1033 
Smylie, M. A., Allensworth, E., Greenberg, R. C., Harris, R., \& Luppescu, S. (2001). Teacher professional development in Chicago: Supporting effective practice. Chicago, IL: Consortium on Chicago School Research. Retrieved from https://consortium.uchicago.edu/publications/teacher-professionaldevelopment-chicago-supporting-effective-practice

WestEd. (2000). Teachers who learn, kids who achieve: A look at schools with model professional development. San Francisco, CA: Author.

Wilson, N. S., \& Bai, H. (2010). The relationships and impact of teachers' metacognitive knowledge and pedagogical understandings of metacognition. Metacognition and Learning, 5(3), 269-288. doi:10.1007/s11409-010-9062-4

\section{About the Author}

Andrew J. Hughes (andrew.hughes@csusb.edu) is Assistant Professor of Career and Technical Education at California State University San Bernardino. 